\section{Sample questions}

1. A 70 year old man is admitted to intensive care with severe community acquired pneumonia. Which of the following regimens would you recommend?

a. Intravenous cefotaxime $1 \mathrm{~g}$ three times a day

b. Intravenous cefotaxime $1 \mathrm{~g}$ three times a day plus clarithromycin $500 \mathrm{mg}$ twice a day

c. Intravenous ceftriaxone $2 \mathrm{~g}$ once daily plus erythromycin $250 \mathrm{mg}$ four times a day

d. Intravenous co-amoxiclav $1.2 \mathrm{~g}$ three times a day plus oral clarithromycin $500 \mathrm{mg}$ twice a day

2. A 52 year old man who smokes and has pneumonia has been taking antibiotics for five days. He is improving clinically. His observations are: temperature $37.3^{\circ} \mathrm{C}$, heart rate $80 / \mathrm{min}$, blood pressure $120 / 80 \mathrm{~mm} \mathrm{Hg}$, respiratory rate $14 / \mathrm{min}$. Which of these statements are correct?

a. It is appropriate to discharge him home

b. He should stay in hospital

c. He should stop his antibiotics

d. He does not need a repeat chest $x$ ray

e. He needs to be seen in clinic in two weeks

- Severe pneumonia (CURB-65 score $\geq 3$ )

- Functional or anatomical reasons for malabsorption

- Impaired consciousness

- Impaired swallowing reflex. ${ }^{1}$

Intravenous antibiotics should be changed to oral as soon as possible. Resolution of the patient's fever, improved oxygen status, and haemodynamic stability are indicators for oral treatment.

In non-severe pneumonia, antibiotics should be given for seven days. Patients with severe pneumonia but no microbiological confirmation usually receive 10 days of intravenous drugs. Patients who are infected with Legionella sp, $S$ aureus, and Gram negative bacteria should receive 14-21 days of antimicrobial treatment.

\section{$\mathrm{C}$ reactive protein}

Measuring $\mathrm{C}$ reactive protein (an acute phase protein) concentrations is useful for managing pneumonia. Ninety five percent of patients admitted with community acquired pneumonia have a $\mathrm{C}$ reactive protein value $>50 \mathrm{mg} / \mathrm{l}^{12}$ The initial concentration of this protein does not correlate closely with the severity of disease, but it can be used as an indicator of response to treatment. Treatment failure or complications (such as an empyema) should be considered if $\mathrm{C}$ reactive protein is not $50 \%$ lower by the fourth day. ${ }^{13}$

\section{When should patients be discharged home?}

It is important to know when it is safe to discharge patients. Features of clinical instability are:

- Temperature $>37.8^{\circ} \mathrm{C}$

- Heart rate $>100 / \mathrm{min}$

- Respiratory rate $>24 / \mathrm{min}$

- Systolic blood pressure $<90 \mathrm{~mm} \mathrm{Hg}$

- Oxygen saturation $<90 \%$
- Abnormal mental status

- Inability to take oral drugs.

One study showed that $40 \%$ of patients who had two or more of these features within 24 hours before they were discharged died or were readmitted within 30 days, compared with $11 \%$ of those with none of these features. ${ }^{14}$

Every patient with pneumonia should be reviewed about six weeks after discharge. In patients with poor clinical recovery, a chest $x$ ray should be done to identify those with possible underlying malignancy. Patients with a high risk of malignancy, such as those who smoke or who are aged over 50 years, should also have a repeat chest $x$ ray at six weeks.

Competing interests: None declared.

1 British Thoracic Society. Guidelines for the management of community acquired pneumonia in adults. Thorax 2001;56(suppl 4):1-64.

2 Macfarlane JT, Boldy D. 2004 update of BTS guidelines: what's new? Thorax 2004;59:364-6.

3 Metlay JP, Schulz R, Li YH, Singer DE, Marrie TJ, Coley CM, et al. Influence of age on symptoms at presentation in patients with communityacquired pneumonia in the community. Arch Intern Med 1997;157:1453-9.

4 Woodhead MA, Macfarlane JT, McCracken JS, Rose DH, Finch RG. Prospective study of the aetiology and outcome of pneumonia in the community. Lancet 1987;I:671-4.

5 Woodhead MA, Arrowsmith J, Chamberlain-Webber R, Wooding S, Williams I. The value of routine microbial investigation in communityacquired pneumonia. Respir Med 1991;85:313-7.

6 Metlay JP, Fine MJ. Testing strategies in the initial management of patients with community-acquired pneumonia. Ann Intern Med 2003;138: 109-18.

7 Fine MJ, Auble TE, Yearly DM, Hanuse BH, Weissfeld LA, Singer DE, et al. A prediction rule to identify low-risk patients with community-acquired pneumonia. N Engl J Med 1997;336:243-50.

8 Lim WS, Van der Eerden MM, Laing R, Boersma WG, Karalus N, Town $\mathrm{GI}$, et al. Defining community acquired pneumonia severity on presentation to hospital: an international derivation and validation study. Thorax 2003;58:377-82.

9 Ewig S, Torres A, Woodhead M. Assessment of pneumonia severity: a European perspective. Eur Respir J 2006;27:6-8.

10 Weber SG, Gold HS, Hoopers DC, Karchmer AW, Carmeoli Y. Fluoroquinolones and the risk of methicillin-resistant Staphylococcus aureus in hospitalized patients. Emerg Infect Dis 2003;9:1415-22.

11 Loo VE, Poirer L, Miller MA, Oughton M, Libman MD, Michaud S, et al. A predominantly clonal multi-institutional outbreak of Clostridium difficile-associated diarrhea with high morbidity and mortality. $N$ Engl $J$ Med 2005;353:2442-9.

12 Hansson LO, Hedlund JU, Ortqvist A. Sequential changes of inflammatory and nutritional markers in patients with community acquired pneumonia. Scan J Clin Lab Invest 1997;57:11-8.

13 Smith RP, Lipworth BJ, Cree IA, Spiers EM, Winter JH, et al. C-reactive protein. A clinical marker in community acquired pneumonia. Chest 1995;108:1288-91.

14 Halm EA, Fine MJ, Kapoor WN, Singer DE, Marrie TJ, Siu AC. Instability on hospital discharge and the risk of adverse outcome in patients with pneumonia. Arch Intern Med 2002;162:1278-84.

\section{Interactive case report}

\section{0 year old man with scrotal swelling, abdominal aortic aneurysm, and renal lesions}

This case was described on 15 and 22 April (BMJ 2006;332:899, 959). Debate on the patient's management continues on bmj.com (http://bmj.bmjjournals.com/cgi/eletters/332/ 7546/899). On 13 May we will publish the case outcome together with commentaries on the issues raised by the management and online discussion from relevant experts and the patient. 